\title{
Regimes, Resistance and Reforms: Comparing Workers' Politics in the Automobile Industry in China and India
}

\author{
Manjusha Nair, George Mason University, United States of America \\ Eli Friedman, Cornell University, United States of America
}

\begin{abstract}
The automobile industry in China was shaken by an unprecedented upsurge of labour unrest in 2010, beginning with the much-discussed wildcat strike at the Nanhai Honda transmission plant in Guangdong province. While worker activism in auto plants in India was not as concentrated as in China's 2010 strike wave, the period 2009-2017 witnessed twenty-seven strikes nationwide, indicating a significant uptick after the global recession. The optimism that regarded the escalation of labour unrest as indicative of a global labour movement emerging from the Global South has died down. This is an appropriate moment to ask the question: Why did these protests not materialise into something more? Existing explanations in China tend to focus on the regime characteristics. In this article, we undertake a much-needed comparative analysis to explore the failure of these protests. We argue that their failure to sustain their momentum, let alone become a global movement, must be understood in the context of the structures and temporality of capitalism. While we show that there were regime-based divergences and national characteristics in each case, we also show the striking global convergence both in the ways that the protests materialised and how the states responded.
\end{abstract}

\section{KEYWORDS}

Labour resistance; temporary work; democracy; neo-liberalism; China; India

\section{Introduction}

The summer of 2010 saw an unprecedented upsurge of labour unrest in the automobile industry in China, beginning with the much-discussed wildcat strike at the Nanhai Honda transmission plant in Guangdong province. The workers' initial demand was for a large wage hike, but their list quickly expanded to include new union elections and a variety of workplace changes. Meanwhile, the Nanhai strike set off a chain reaction around the country as strikes erupted in supplier plants for Honda and other foreign automakers. In most cases, workers won large wage increases, and government officials began openly discussing implementing the right to strike and to bargain collectively. Since then, however, officials both within Guangdong and at the national level have moved in a decidedly pro-capital direction, as the state has become increasingly concerned with slowing growth.

While worker activism in auto plants in India was not as concentrated as in China's 2010 strike wave, the period between 2009 and 2017 witnessed twenty-seven strikes nationwide, 
indicating a significant uptick after the 2008 global recession. ${ }^{1}$ Like their counterparts in China, striking Indian autoworkers demanded representative unions, wage hikes, job security and an end to draconian work discipline. The height of this unrest was a wildcat strike in 2011 by around 3500 workers at the Maruti-Suzuki assembly plant in the Industrial Model Town in Haryana state. The confidence that workers gained by the partial success of many strikes was offset by the suppression of the unrest in Maruti-Suzuki. In 2012, 147 workers were held without bail on murder charges, and 550 regular and 1800 irregular workers were terminated. ${ }^{2}$ The BJP-led state government in Haryana and the national government, meanwhile, began instituting anti-labour reforms.

Labour scholars were optimistic that the escalation of labour unrest shown in these strikes was indicative of a global labour movement emerging from the Global South. Immanuel Ness (2016: 24) claimed that, "In the South, rank-and-file workers are challenging existing unions to demand more than a raise - in effect a restructuring of society for all workers". Many others talked about these protests as symptomatic of labour revitalisation and the potency of automobile workers to organise and resist capital (Zhang, 2015; Nowak, 2019). Yet, although some labour reforms were introduced in China and firm-level unions were recognised in India, the future seems bleak for labour politics in both countries. The political weakness of Chinese workers has been underlined by the government's increasing hostility to labour interests, and the democratic rights of Indian workers have been curtailed through coercion as well as the re-regulation of labour by a clearly pro-business government. In both countries, nationalist sentiment has further eroded the potential for widespread working-class mobilisation against capital and the state.

Until now, labour protests in China have mostly been analysed nationally (Gallagher, 2017; Kuruvilla, 2018; Howell and Pringle, 2019). In this article, we offer a comparative analysis of labour protests in India and China. We show that there are more convergences than might be expected in terms of the character of labour protests as well in state and industry responses. The workers' demands for a democratic workspace was derived from the tight labour regime put in place by the lean production system and flexible production, resulting in demands for more workplace democracy, a part of the trajectory of global capitalism, especially the uptick in production due to the global financial crisis. But there were differences as well: the Chinese state has, somewhat surprisingly, been more responsive to protests, institutionalising a few pro-labour reforms, while the Indian state has been more repressive towards striking autoworkers and has been enacting a series of pro-capital labour reforms.

We argue that worker unrest in the automobile industry in China and India can be characterised as what we call "fractured militancy". ${ }^{3}$ By this we mean the presence of a multitude of actors engaged in regular, confrontational forms of protest at the point of production, without the emergence of a trans-local collective movement with common objectives. Fractured militancy in China and India is economically disruptive, but autoworkers in today's Global South are no longer able to lead movements for political transformation. These struggles are not indicative of the emergence of a politically potent labour movement. Although the two countries have followed very different trajectories, decentralisation and growth-oriented local and central governments have produced a hostile political terrain for labour in both. What is more,

\footnotetext{
${ }_{1}$ Two-wheelers, passenger cars and utility vehicles are included here in the analysis of automobile production and protests in India.

2 As "irregular workers" we include contract, temporary, dispatch and intern workers.

${ }^{3}$ We would like to note that Marcel Paret (2018) has also used this term with reference to protest in South Africa. We arrived at the term independently.
} 
twentieth-century institutions of labour representation have not established autonomous political power for an internally segmented working class increasingly composed of migrants and irregular workers. Finally, with the complicated legacy of socialism, the end of the cycle of national liberation movements, and no further waves of democratisation on the horizon, worker resistance has been almost exclusively concerned with workplace-based issues, and anti-state politics are off the table (Huntington, 1991; Diamond, 1996).

Our focus on autoworkers is informed by the historically significant role that they have played in building powerful labour movements in other countries. Autoworkers are not representative of the working class in general but have proven vital in building working-class power in heterogeneous social and historical situations. In what follows we provide a multi-level analysis based on dynamics in the firm, the industry and the state in each country. We begin by looking at two strikes, the 2010 Nanhai Honda strike in Guangdong's Pearl River Delta and the 2011 Maruti-Suzuki strike in the Gurgaon district of Haryana. We situate these strikes in the broader context of insurgency in the automobile sector of those manufacturing hubs. We then assess the outcomes of these strikes and their impact on the automobile industry. Throughout, we are attentive to state responses, both their resolutions of these respective strikes as well as in the broader legal and policy environment. While we do not claim that the reforms we analyse are direct outcomes of these individual strikes, legal changes provide important context within which we situate the strikes.

Evidence has primarily been generated by field observations in Guangdong and Gurgaon and interviews with autoworkers, rank-and-file union members and trade union leaders. We also rely on news reports, official documents and secondary literature. The section on Guangdong is informed by fieldwork conducted over a number of visits in 2008-2010. During this research, we interviewed primarily union officers, both in the Guangzhou-based Honda joint venture as well as in provincial and municipal union federations. This was then supplemented by additional interviews in 2013 with workers, managers and union representatives. In Gurgaon, we interviewed union representatives and workers from eight assembly and supplier firms inside the factory premises in December 2014. We also interviewed permanent and temporary workers, expelled workers, lawyers, trade union representatives and labour movement scholars. We participated in workers' meetings, marches and a joint protest outside the district magistrate office. Apart from one electronic component manufacturing firm, all workers that we interviewed in Gurgaon were male and the majority were rural-to-urban migrants. All workers were young, articulate and toyed with their iPhones or Androids during the meetings. They were graduates of vocational technical schools, and their children, even those of temporary workers, attended private English-medium schools. In other words, these first-generation migrants held aspirations of social mobility in urban India.

\section{A Global Labour Renaissance?}

Analysing the spatial and temporal patterns of capital mobility and labour movements historically, Beverly Silver (2003) has pointed out that wherever capital in the automobile industry relocated, strong working-class movements emerged. Automobile sector militancy shifted from North America in the 1930s and 1940s to Europe in the post-war period and then to newly industrialising countries such as Brazil, South Africa and South Korea in the 1970s. With the immense strength generated by their position in the division of labour, these workers were able to shape and expand the boundaries of unionism. Thus, militant autoworkers have played a decisive political role in reshaping broader labour-capital relations in each new site of capitalist 
expansion.

At the risk of oversimplification, a first wave of insurgent movements in early to mid twentieth-century North America and Western Europe were incorporated into formally democratic state structures via legal reforms, institutionalisation of labour relations and an expansion of welfare states. Under such a class compromise, workers agreed not to challenge the private ownership of the means of production or capital's prerogative to organise production, in exchange for job security, better compensation and state-subsidised social reproduction (Przeworski, 1986). Autoworkers certainly did not bring about these shifts single-handedly but did play a central political role in numerous industrialising countries. ${ }^{4}$

A second wave of politicised labour unrest emerged in the Global South in the latter half of the twentieth century. The three paradigmatic cases of South Africa, South Korea and Brazil, all of which had experienced rapid industrialisation in the 1970s under US-supported authoritarian governments, reveal important differences from the earlier wave. Frequently interpreted as "social movement unionism", ${ }^{5}$ workers in each of these countries built bonds of solidarity with community members and other groups while formulating a set of political demands that extended beyond the workplace (Seidman, 1994; Koo, 2001). In all three of these countries, worker grievances were articulated in an environment in which anti-colonialism, anti-imperialism and socialism held mass appeal. And in all three cases, labour movements played a crucial role in bringing about democratisation.

In the twenty-first century, the auto industry has expanded rapidly in both China and India. Each country has experienced a surge of activism among autoworkers over the past decade. These developments raise this question: are we witnessing a third wave of politically transformative labour movements?

Some scholars believe so. Citing the 2011 Maruti-Suzuki strike in India, Jörg Nowak (2017, 2019) has argued for the presence of a new form of social movement unionism that does not integrate workers and subalterns into national trade union confederations. Organised on a local and regional level, these movements have been interpreted by Nowak as a potential early stage of a new resistance movement which later could become the basis for national-level unrest. Similarly, Lu Zhang (2014) has argued that striking workers in China's automobile factories were making rights claims, which shows the potential for a third wave of labour activism emerging from the Global South, while Immanuel Ness (2016: 24) has claimed that workers in the Global South are demanding a restructuring of society in general.

This optimism has been misplaced. Mary Gallagher (2017) argues that the Chinese government has deliberately chosen suboptimal methods of labour rights enforcement that maintain state legitimacy, improve social stability and provide flexibility to maintain political control over labour movements. Patricia Chen and Mary Gallagher (2018) have argued that political fixes by the Chinese government are the reason behind the failure of broad-based labour movements to emerge in contemporary China. According to Vincent Chen and Anita Chan (2018), a paternalistic and humanistic management system has mitigated the worker

\footnotetext{
${ }^{4}$ The catalytic role of the Flint sit-down strike in US labour history is one of the best-known examples.

${ }^{5}$ For an overview of the debate see the symposium on The Future of Social Movement Unionism, Employee Responsibilities and Rights Journal, 20(3), 2008, https://link.springer.com/journal/10672/volumesand-issues/20-3.

${ }^{6}$ Our use of the term "wave" is somewhat distinct from that of Burawoy. Whereas he refers to a third wave in which resistance shifts from the industrial to service workers in the Global North, we are concerned with spatial shifts of industrialisation and its attendant labour unrest, from North to South. See Burawoy (2008).
} 
dissatisfaction of both regular and agency workers and hence, agency workers may not participate in resistance movements. C.K. Lee (2016) has countered this argument by stating that employers and local government officials collude with each other and continue to implement labour laws arbitrarily. In a comparative analysis of the interplay between global involvement and political placement of trade unions in China, Mexico and France, Dorothy Solinger (2007) has suggested that it is the absence of unions that leads Chinese workers to resist.

Our objective in the article is to go beyond a comparison of the labour politics of China and India. There are indeed differences in mobilisation, organisational capabilities and militancy within these vastly different governments. Rather, we point to a global neo-liberal convergence in labour politics and state responses beyond what could be explained by regime type (democracy versus strong central state). In both cases, instances of fractured militancy with limited reforms and repression from the state are present. As Prasenjit Duara and Elizabeth Perry have noted:

The alternative view [to methodological nationalism] by no means denies the role of national institutions and politics as a major frame of reference; rather it urges us to appreciate that particular developments within nations are conditioned as much by subnational currents as well as circulatory global forces as by purely national or internal processes (Duara and Perry, 2018: 23).

This brings us to the role of the state in shaping and responding to labour unrest. Scholars no longer assume that globalisation brings about a powerless state (Weiss, 1998; Seidman, 2007; Rodriguez, 2010). States are important actors, not only in their capacities as rule makers and law enforcers, but also and at the same time as interest bearers in capitalist expansion and legitimacy bearers from the citizenry. And yet, the role of the state is far from uniform, and in this case study deploying the regime typology of "democracy" and "authoritarianism" is not useful. Indeed, the Indian state appears to be more repressive towards wildcat strikes than the Chinese state, despite the latter's well-documented preoccupation with social unrest (Wang and Minzner, 2015).

\section{Labour Insurgency and Taming Dissent in China}

Auto manufacturing has become of immense economic importance in China, with auto producers accounting for 9 per cent of all industrial profits (All China Data Center, 2015). Foreign companies wishing to produce in China have been required to establish joint-venture assembly plants with local state-owned firms - a necessary step to cash in on the explosive growth in the world's largest auto market. A number of auto clusters have developed in the country, including around Guangzhou, Shanghai, Wuhan, Chongqing and Changchun. Parts suppliers are a diverse mix of mostly foreign firms. In general, wages and benefits are strong in the assembly plants (reflecting their tradition as state-owned firms), although many companies increased their use of irregular workers through the 1990s and 2000s.

Lu Zhang (2011) estimates that one-third to one-half of the production workforce in the auto industry are agency workers. Labour unrest has been concentrated in the supplier factories, though forms of resistance have appeared in assembly plants as well. The lean production system has produced multiple labour regimes in various sectors and nodes of the supply chain. In China's automobile companies, trade unions usually have a relatively secure position and are coopted into factory management. In comparison, in the supplier ventures, where labour control follows authoritarian paternalism, wages are minimal, overtime is the rule and unions are absent (Lüthje, 2014). Not surprisingly, labour unrest has happened in these supplier units. 
The 2010 Nanhai Honda strike has received ample treatment in the scholarly literature (Butollo and Brink, 2012; Chan and Hui, 2014; Friedman, 2014), so we will not provide a comprehensive account of the events. Nonetheless, a brief review of that summer's labour unrest is necessary. Most of our attention, however, will be devoted to assessing events following this important strike, which at the time was hailed as a turning point in Chinese labour relations.

On 17 May 2010, a small group of workers at the Nanhai Honda transmission plant, dissatisfied with their wages, staged a wildcat strike. Although most of the nearly 2000 workers in the plant had not been involved in strike preparations, the strikers' demand for an RMB 800 wage hike (an increase just under 50 per cent for most workers) was widely embraced, and the strike spread to the factory's other workshops. Both regular and irregular workers were active participants. Over the course of the next three weeks and several rounds of negotiations, the Nanhai Honda workers were able to sustain what was at the time almost certainly the longest running strike in a private firm. Dissatisfied with the fact that their official union largely sided with management during the negotiations, workers demanded the right to reorganise the union and hold elections. After the Guangdong Federation of Trade Unions (GDFTU) became involved, worker representatives accepted a wage hike of approximately RMB 500 for regular workers and somewhat higher than that for irregular workers. The GDFTU leadership also promised to preside over new union elections.

Even before the Nanhai negotiations were over, a strike wave engulfed much of China's auto parts industry (see Table 1). In many cases, workers followed the lead of the Nanhai workers and demanded new union elections as well as wage hikes. Often with the support of their enterprise unions, which now sided with the strikes, most of the striking workers won major wage hikes. The strikes even spread beyond the auto sector, and some enterprises gave workers a pre-emptive raise. In Guangzhou alone, there were strikes in more than sixty enterprises, many of them outside of the auto sector (Weiguang, 2011). Although it is impossible to know the precise number of strikes that took place in Guangdong during the summer of 2010, it is clear that the government was concerned about the instability and was willing to push employers to compromise in order to resolve strikes.

Big wage hikes helped ameliorate the immediate crisis, but certain segments of the state recognised that there was a systemic problem with labour relations. Indeed, while Nanhai had captured the headlines, there had been growing unrest in the auto industry for some time leading up to 2010. And strikes had been increasing not just in auto, but in other industries as well, particularly in Guangdong (Elfstrom and Kuruvilla, 2014). In a major departure from the past, sympathetic officials in Guangdong and Beijing began openly discussing legislating the right to strike. The Guangdong provincial government proposed a set of regulations on "democratic enterprise management" which had originally been raised in 2008 but was subsequently shelved as a result of the economic crisis. The regulations would allow for collective negotiations if onefifth of employees demanded this (21 Shiji Jingji Baodao, 2010). It appeared that a significant realignment in labour relations was afoot.

However, the proposed regulations were opposed by employer organisations, most notably the Hong Kong General Chamber of Commerce, and never implemented. In 2014 the Guangdong provincial government enacted the "Regulations on Enterprise Collective Contracts". The centrepiece of these regulations was a requirement that enterprises engage in collective negotiations if more than 50 per cent of employees demand it. There were additional provisions to protect bargaining representatives from reprisal, guidelines (though no requirements) for democratic representative elections, and specific timeframes within which management would be required to respond to a request for negotiations. 
Table 1. Auto industry strikes in China, 2009-2011**

\begin{tabular}{|c|c|c|}
\hline Firm Name & Place & Date \\
\hline Changan Ford Mazda Automobile Co., Ltd & Nanjing & March 2009 \\
\hline Guangzhou H Auto Parts Industries Inc. & Guangzhou* & June 2009 \\
\hline Wuhan Auto Parts Alliance Co., Ltd. & Wuhan & June 2009 \\
\hline Wuhan Wanshun Auto Parts Co., Ltd. & Wuhan & July 2009 \\
\hline Guangzhou Moriroku Technology Co., Ltd. & Guangzhou* & July 2009 \\
\hline F.tech Zhongshan Inc. & Zhongshan* & January 2010 \\
\hline Gensho Shibusawa Logistics (Guangzhou) Co., Ltd. & Guangzhou* & January 2010 \\
\hline Akebono Corporation (Guangzhou) & Guangzhou* & January 2010 \\
\hline China FCC Foshan Co., Ltd. & Foshan & February 2010 \\
\hline Yurozu Bao Automotive Co., Ltd. & Guangzhou* & February 2010 \\
\hline Guangzhou Linjun Co., Ltd. & Guangzhou* & March 2010 \\
\hline Guangzhou Automobile Industry Group (GAIG) & Guangzhou* & March 2010 \\
\hline Guangzhou Xing Guang Metal Co., Ltd. & Guangzhou* & March 2010 \\
\hline Guangzhou Hexi Auto Parts & Guangzhou* & March 2010 \\
\hline Qijiang Gear Transmission Co., Ltd. & Chongqing & May 2010 \\
\hline Honda Auto Parts Manufacturing (CHAM) Co., Ltd. & Nanhai* & May 2010 \\
\hline FUJI Chemical Co., Ltd. & Zhongshan* & June 2010 \\
\hline Toyoda Gosei Co., Ltd. & Tianjin & June 2010 \\
\hline Nihon Plastic Co. & Zhongshan* & June 2010 \\
\hline Wuhan Auto Parts Alliance Co., Ltd. & Wuhan & June 2010 \\
\hline Toyoda Gosei Starlight Rubber and Plastic Co., Ltd. & Tianjin & June 2010 \\
\hline Honda Lock (Guangdong) Co., Ltd. & Zhongshan* & June 2010 \\
\hline Foshan Fengfu Autoparts Co., Ltd. & Foshan* & June 2010 \\
\hline Omron (Guangzhou) Automotive Electronics Co., Ltd. & Guangzhou* & July 2010 \\
\hline Atsumi Metal Co., Ltd. & Foshan* & July 2010 \\
\hline Guangzhou Ahresty Casting Co., Ltd. & Guangzhou* & April 2011 \\
\hline Sanqiao (Guizhou) Auto Parts & Guizhou & April 2011 \\
\hline Kumho Tire (Changchun) Co., Ltd. & Changchun & June 2011 \\
\hline NHK-UNI Spring (Guangzhou) Co., Ltd. & Guangzhou* & June 2011 \\
\hline Denso (Guangzhou Nansha) Co., Ltd. & Guangzhou* & June 2011 \\
\hline Guangzhou Ahresty Casting Co., Ltd. & Guangzhou* & $\begin{array}{l}\text { December } \\
2011\end{array}$ \\
\hline Shanghai Delphi Automotive Air Conditioning Co., Ltd. & Shanghai & $\begin{array}{l}\text { December } \\
2011\end{array}$ \\
\hline
\end{tabular}

*indicates city within Guangdong Province. **This list is non-exhaustive.

Sources: China Labour Bulletin Strike Map, http:/ / www.iblo.org/LRC/W/000710.pdf

While this seemed like a decisive step towards implementing a more robust labour relations framework, in fact the regulations fell short in a number of key areas. The regulations explicitly ban strikes while negotiations are taking place yet provide no requirements for bargaining in good faith or binding arbitration. Instead, management can bargain indefinitely without making any concessions, thereby rendering any strike activity illegal.

Following the Nanhai strike, the GDFTU had promised to directly supervise new elections. 
But it became clear quite quickly that the elections were going to be very tightly managed to ensure that activists would be excluded from union leadership. Rank-and-file workers were unable to freely participate in electing the union chairperson and executive committee, as incumbents tightly controlled all nominations for higher-level union officers (Lau, 2012). A union-produced booklet on successful cases of collective negotiations in Guangzhou from 2010 and 2011 indicates that elections in other factories were similarly restrictive. For instance, in recounting the success of negotiations at the NTN auto parts factory, the booklet reports, "representatives must meet the following conditions: A) rationality, objectivity, familiarity with the company's development; B) ability to represent their department; C) selected representatives

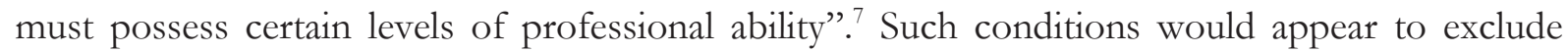
unskilled workers and activists. And legally, there has been no change whatsoever to encourage greater independence for unions. Chinese workers continue not to see their unions as legitimate representatives (Chen, 2003).

Although the state has kept a tight grip on unions, it does appear as if the high level of strike activity in Guangdong's auto sector led to a degree of regularisation of firm-level collective bargaining. The union chair from Denso, a Japanese-owned parts factory that experienced a wellorganised and militant strike in 2010, commented on this development in an interview, explaining, "I think that the 2010 strike wave had a huge effect on subsequent wage increases... if this factory has a strike, it can give society a point of reference. It's a warning to capital" (Interview, 3 December 2013).

In describing the process of negotiations one year after the strike, the union chair at Guangzhou Shiroki, another Japanese parts supplier, detailed the sort of back and forth that is typical of collective bargaining in other countries. After the union proposed a 100-yuan wage hike, management countered with an offer of an RMB 20. In the end, the union settled for a fifty-yuan bonus, with the chair commenting, "both labour and capital made some compromises" (Interview, 16 November 2013).

How long management will remain willing to bargain in good faith in the absence of independent unions or the right to strike is debatable. Indeed, two years after the above interview, the very same union chair from Shiroki found himself up against an intransigent bargaining opponent. Beginning in March 2015, eight separate meetings took place between representatives from the union and management. After their initial offer of an 8.5 per cent wage increase was rejected, management insisted that 8.7 per cent was their final offer. After two and a half months and eight rounds of negotiations, the union chair said that he would put the 8.7 per cent wage hike to a vote, as was his right. But management refused to make the arrangements for workers to attend the meeting where they would vote on the proposal, unless the negotiating team gave the proposal their support. As the worker representatives were unwilling to do this, management unilaterally imposed a contract on June $9 .{ }^{8}$

Even before the strike wave, union leaders in Guangdong had expressed interest in building sectoral unions - that is, unions that negotiate collective agreements for all of the employers in a given industry and region. Since 2010, there have been increased indications of informal coordination between auto parts suppliers in the Pearl River Delta. A union chair at the Denso plant in Guangzhou's Nansha district described how he and union representatives from other

\footnotetext{
7 "shi da anli" internal union booklet.

${ }^{8}$ Information in this paragraph comes from an open letter penned by the union chair to higher levels of the union (http://weibo.com/p/1001603855394173801448? from=page 100606 profile\&wvr=6\&mod= wenzhangmod).
} 
neighbouring plants would get together occasionally to discuss conditions in their workplaces. But they did not set up a formal organisation, leaving labour at a disadvantage (Interview, 3 December 2013). In Luogang District of Guangzhou, the municipal union federation established the Luogang District Auto Parts Union Association in 2011, with the intent of experimenting with district-wide collective negotiations. As of the end of 2013, this had not yet happened, but union leaders were in regular contact with each other. Union officials from the municipal and provincial levels had played an important role in bringing people together. But practically speaking, collective negotiations in the auto industry remain decentralised at the firm level, and any coordination is informal (Friedman and Kuruvilla, 2015).

At the national level, the central government took a number of steps between 2012 and 2014 to re-regulate the employment of irregular or so-called "dispatch" workers, which had expanded rapidly in the auto and other industries after 2008. Dualisation and irregular employment were factors underlying the 2010 strike wave, even if many strikes in part supplier factories were led by formal workers. Largely in response to the efforts of national union leadership, in late 2012 the government revised the Labour Contract Law to clarify the definition of dispatch labour and impose new restrictions on labour contracting agencies, a move intended to ameliorate a major source of friction in the auto and other industries. Then, in 2014, the Ministry of Human Resources and Social Security issued a set of regulations that restricted use of dispatch labour to 10 per cent of the total workforce. Companies were given two years to comply with the new regulations, so it is still too soon to fully assess the impact on dualisation in the auto sector. However, early indications suggest poor enforcement and widespread legal evasion (Gongren Ribao, 2016).

By 2015 it became clear that such compromises were becoming a thing of the past, as the state became increasingly preoccupied with maintaining social stability and propping up slowing growth. Fewer provinces increased their minimum wages, and those that did so increased the standard by smaller amounts. In 2012, twenty-five provinces increased their minimum wages by an average of 20.2 per cent, whereas in 2016 only nine provinces adjusted the minimum wage, by an average of 10.7 per cent. Guangdong Province released a wage reduction plan for 2016 to 2018. Under this plan, the government would wait three years to adjust the minimum wage (despite a national regulation requiring adjustments every two years) (Xinhua Wang, 2017).

The above illustrates how China's national union leadership has abandoned its rhetorical commitment to collective bargaining, and experiments with sectoral unions have been downplayed. Although labour NGOs in the Pearl River Delta had been playing an increasingly active role in assisting striking workers in collective bargaining (while avoiding calling for strikes), these union-like activities were ended in December 2015, when a number of prominent labour activists were arrested (Franceschini and Nesossi, 2018).

\section{Labour Insurgency and Suppressing Dissent in India}

Until the 1980s, a handful of Indian firms, mostly private, produced passenger and commercial vehicles in an economy that was protected from global competition through import substitution and heavy state regulations. Passenger vehicles such as cars were deemed a luxury commodity by the state and an indulgence by the rich in popular discourse. ${ }^{9}$ It was only in the 1980s, with the

\footnotetext{
${ }^{9}$ For instance, the villains and "exploitative" businessmen in Indian movies used to ride in imported Mercedes Benz and Chevy Impala cars.
} 
ascent of a middle class and an emerging domestic market, that serious investment in automobile production began. The Indian government started a joint venture with the Japanese Suzuki Corporation (Maruti Suzuki India Limited, MSIL) in 1981. This joint venture has been the most important contributor to the almost threefold increase in passenger car production between the 1980s and 1990s and has been the principal source for restructuring the Indian automobile industry in the production of two-wheelers and commercial vehicles (D'Costa, 1995). Local component restrictions were removed in 1993, the state share in MSIL declined from 80 per cent to a mere 18 per cent, and the company was completely privatised in 2007 (D'Costa, 2007). Currently around twenty-five global players and a few Indian corporate groups have invested in cars, two-wheelers, commercial vehicles and numerous component manufacturing enterprises. This process has been facilitated by a flexible industrial climate that allows 100 per cent foreign ownership in the auto sector, as well as local engineering expertise, cheap labour and an expanding domestic market. The auto industry is geographically clustered in four large manufacturing hubs in India, Gurgaon district in Haryana state being part of the one in the National Capital Region. Just as in other parts of the world, the Indian auto industry is vertically organised into a multi-tier system comprised of multinational and local firms in multiplex networks (Gereffi, Humphrey and Sturgeon, 2005).

In 2016, the automotive industry accounted for 45 per cent of India's manufacturing gross domestic product (GDP), 7.1 per cent of the country's GDP, and employed about nineteen million people. India is the sixth largest producer of commercial and passenger cars, and the fifth largest passenger vehicle and commercial vehicle market (Make in India, 2021). The "Make in India" initiative of Prime Minister Narendra Modi that started in 2014 has provided numerous incentives to automobile companies; it aims to make the Indian auto industry the prime mover of the manufacturing sector and create an additional sixty-five million jobs (Make in India, 2021). According to projections by the state, India is expected to be the third-largest automotive market by volume by 2026, given the growing working population and an expanding middle class.

The industry relies heavily on irregular work to diffuse costs across the supply chain. In the more formalised assembly and component manufacturing plants, irregular workers recruited through contractor middlemen form almost three-fourths of the workforce. They often possess similar skills as the regular workers and do the same jobs, but in most cases are paid just the minimum wage while skilled workers in Haryana state were paid four to five times higher wages. The difference often escalated. Thus, in Hero MotoCorp, the regular workers received a salary of 45000 to 50000 INR per month, while irregular workers received the minimum wage of 5500 INR per month (Interviews with regular workers, 19 December 2015). And the benefits of regular work declined as one climbed down the tiers. The lowest ends of the supply chain were far removed from the formal economy, and the lanes and alleys in Gurgaon that we visited were layered with home-based workshops employing informal labour (Posthuma and Nathan, 2010).

The Maruti-Manesar strike has received media and scholarly focus (Annavajhula and Pratap, 2012; Sarkar, 2015; Nowak, 2016)..$^{10}$ Unrest has been a persistent feature in the automobile sector often characterised by violence and massive production loss (Jha and Chakraborty, 2014) (see Table 2). Protests have taken place consistently over the years in all automobile hubs under all kinds of ownership and across the supply chain.

Earlier strikes won some concessions. The Honda workers' strike in 2005 was the first to gain media attention, when around 1500 regular workers and 3000 irregular workers registered their own union affiliated to the All India Trade Union Congress (AITUC), against the wishes of

${ }^{10}$ See also https://gurgaonworkersnews.wordpress.com, newsletters from 2007 to 2016. 
the management-sponsored union. This was followed by the mass suspension and termination of workers. After a police assault on a rally of Honda workers at the District Labour Commissioner's office, the then-Congress Party central government resolved the conflict. In the end, the suspended and terminated workers were taken back, though only the permanent workers received a tremendous wage hike and other provisions. Workers of Munjal Showa, an Indian and Japanese venture, came to a tripartite agreement in 2011 after which 250 workers were made regular, a wage hike was provided and a work committee with equal representation by managers and the workers - but not a union - was allowed.

Table 2. Auto industry strikes in India, 2009-2017**

\begin{tabular}{|c|c|c|}
\hline Firm Name & Location, State & Date \\
\hline Mahindra and Mahindra Ltd. & Nashik, Maharashtra & May 2009 and March 2010 \\
\hline Sunbeam Auto Pvt. Ltd. & Gurgaon, Haryana* & May 2009 \\
\hline Bosch Chassis Systems India Ltd. & Pune, Maharashtra & July 2009 \\
\hline $\begin{array}{l}\text { Honda Motorcycle and Scooter India } \\
\text { Pvt. Ltd. }\end{array}$ & Manesar, Haryana* & August 2009 \\
\hline Rico Auto Industries & Gurgaon, Haryana* & August 2009 \\
\hline Pricol Ltd. & Coimbatore, Tamil Nadu & September 2009 \\
\hline Volvo India Pvt. Ltd. & Hoskote, Karnataka & August 2010 \\
\hline MRF Tyres Ltd. & Chennai, Tamil Nadu & October 2010 and June \\
\hline General Motors India Pvt. Ltd. & Halol, Gujarat & March 2011 \\
\hline Hyundai Motor India Ltd. & Chennai, Tamil Nadu & April 2011 \\
\hline Maruti-Suzuki India Ltd. & Manesar, Haryana* & June-August 2011 \\
\hline Bosch in India Ltd. & Bangalore, Karnataka & September 2011 \\
\hline Dunlop Tyres Ltd. & Hooghly, Bengal & October 2011 \\
\hline Caparo Vehicle Products India Ltd. & Sriperumbudur,Tamil Nadu & December 2011 \\
\hline Hyundai Motor India Ltd. & Chennai, Tamil Nadu & December 2011 \\
\hline Dunlop Tyres Ltd. & Ambattur, Tamil Nadu & February 2012 \\
\hline Maruti-Suzuki India Ltd. & Manesar, Haryana* & July 2012 \\
\hline Bajaj Auto Ltd. & Pune, Maharashtra & June 2013 \\
\hline Bosch in India Ltd. & Bangalore, Karnataka & November 2013 \\
\hline Napino Auto and Electronics Ltd. & Gurgaon, Haryana* & March 2014 \\
\hline Shriram Pistons and Rings Ltd. & Alwar, Rajasthan & April 2014 \\
\hline ASTI Electronics India Pvt. Ltd. & Manesar, Haryana* & December 2014 \\
\hline Bridgestone Tyres India Ltd. & Manesar, Haryana* & September 2015 \\
\hline Maruti-Suzuki India Ltd. & Manesar, Haryana* & September 2015 \\
\hline Tata Motors Ltd. & Sanand, Gujarat & February 2016 \\
\hline Honda Motorcycles and Scooters Ltd. & Alwar, Rajasthan & March 2016 \\
\hline AISIN Automotive Ltd. & Rohtak, Haryana & May 2017 \\
\hline
\end{tabular}

The Maruti-Suzuki plant in Manesar, where forty-eight cars were produced in one minute, in many ways epitomised lean production. But workers' obedience was secured in this plant through stringent discipline that reflected a despotic Fordist factory regime of the early 1900s more than the participatory management that lean production envisaged: when the car rolled in the assembly line to their work station, the worker had to choose between the 180 variants of the three cars produced at the plant and match the part to the car in an average of fifty seconds per car (Jha and Chakraborty, 2014; Sethi, 2016). There were no relievers, and workers received extremely short breaks - seven and a half minutes to use the washroom, have tea and snacks, and return to the workstation (Interview with a terminated worker, 10 December 2014). When domestic demand 
for cars increased after 2008, management increased production. This uptick in production required a more stringent labour regime, with no comparable rise in incentives, and protests soon broke out. The main demand was a democratic union. In 2011, workers at the plant decided to register their own union, the Maruti Suzuki Workers' Union, in the Haryana state capital of Chandigarh. Legally, union registration can be done without informing management; in this case, the workers believed that management received a fax from the registrar's office with the news of the union formation. Shortly thereafter, workers alleged that, to forestall the formation of a union, management suspended a handful of workers, citing indiscipline, and started taking workers' signatures on blank papers, which was intended to create fear among the remaining workers.

The workers refused to sign these blank papers and launched a strike in June 2011. Around 3500 workers participated in the strike, including irregular workers despite the fact that they could not be legally represented by the union. After thirteen days, management agreed to the formation of the union and reinstatement of the suspended workers. But the agreement was not honoured and instead the workers were asked to sign a good conduct undertaking that restricted them from any work stoppage or activity that would hamper production. In response to this, workers launched a second strike, after which management suspended ninety-five workers. Eventually, management agreed to recognise the union, but insisted that it only represented regular workers and refused to reinstate forty-five irregular workers. Workers then struck for a third time to reinstate the suspended workers and for wage parity for irregular workers. But management bribed thirty leaders, and the strike was broken.

In July 2012, a dispute between a worker and his supervisor blew up into a heated argument when the latter used a caste-based remark against the former. Violence erupted in a subsequent meeting and a human resource manager of the firm was asphyxiated to death in a fire of ambiguous origin. After this incident, 550 regular workers and 1800 irregular workers were arbitrarily blamed for the incident and fired. In an unprecedented act, 147 workers were arrested on charges of murder, arson and rioting, and their bail plea was rejected by the Haryana High Court. They were held without bail or trial for over two years. Finally, in March 2017, thirteen of them were given life sentences and five short-term sentences. The rest were acquitted or let off with a fine.

Meanwhile, management introduced some conciliatory measures in the plant. A union election was held in 2014 and the workers' candidates won eleven out of the twelve seats, gaining 85 per cent of the total votes. The union has subsequently negotiated wage, workload, leave and bonuses agreements, but only for regular workers. As a result, irregular workers struck in September 2015 against the new wage agreement that had increased their wage gap with regular workers. They argued that this new agreement between the union and Maruti-Suzuki management jeopardised the possibility of any future joint action by regular and irregular workers.

Workers in the Hyundai Motor Company plant near Chennai struck in 2012, demanding union representation and the reinstatement of twenty workers who had been suspended for forming a union. Unlike in Haryana, the Tamil Nadu populist-led government initiated negotiations between Hyundai management and trade unions that resulted in an agreement. The strike was called off after fifteen days, but workers received no back wages, their union was not recognised and their demands for relaxing the factory environment were not accepted (Shin, 2014). In Maharashtra, workers at the Bajaj auto plant struck in 2013 against stringent work discipline and the suspension of twenty-one workers. They also demanded equity shares in the company. Management refused to negotiate with the workers, terming their demands "insane", 
and the strike was called off after fifty days (Nowak, 2019). ${ }^{11}$ Though Gujarat has a history of peaceful and conciliatory management of industrial relations following the Gandhian model (Duvisac, 2019), the Tata Nano strikes in 2016 failed to elicit a management response. Thus, while workers' protests did follow the new spatial locations of the automobile industry as Silver (2003) suggested, in each site these protests were tamed and protestors isolated, often using coercion.

During our field visit, Gurgaon indeed appeared to be the epicentre of workers' unrest, receiving such characterisation in scholarly and activist discourse. Though we initially did not have any contacts in Gurgaon, just a visit to the AITUC office on the first day yielded seventeen potential informants. Workers mentioned support from across firms, unions and the wider political community during the strikes. Jailed workers were provided legal and financial aid, and solidarity marches were organised around village communities. Central trade unions and independent unions were members of a joint council of trade unions. There were mobilisations across workers, unions, student activists from Delhi universities and communist mass organisations.

Yet, we found little evidence of these protest movements collaborating with central tradeunion-affiliated unions in the industry and becoming a sustained movement capable of a persistent struggle for reforms. Affiliation with a central trade union had provided striking workers with some external support, but this was short-lived. In the companies with an AITUCaffiliated union that had had successful strikes before 2011, workers survived on food packages from their fellow unionists. Once the settlement was reached with management, however, workers seemed content with their bargain. The union president of Napino Auto commented, "Now we have a union of twelve body members. Some keep a watch on the production line because we care about production. We have become company workers. We got service security and we get salary increase every three years" (Interview, 9 December 2014).

The two assembly plants of Maruti-Suzuki had two distinct independent unions with separate jurisdictions. Apart from these, Maruti-Suzuki had an engine plant, which was located inside the Manesar assembly plant and a Suzuki motorcycle plant, both of which had unions affiliated with a central trade union. The motorcycle plant workers complained that their attempts to have a combined bargaining body for all four plants were only partially successful (Interview, 9 December 2014). ${ }^{12}$ As the union president from a tier one firm put it,

My union activity is confined to my plant. I do not want to interfere in outside activities. I do meet everyone and support everyone; I maintain good relations with all unions. But independent union means no tension, just our owner and us. We don't want any other problem. We want the plant to run (Interview, 12 December 2014).

Meanwhile, the central and regional states have been instituting pro-capital labour market reforms (Gopalan, 2016). Labour regulations are in the concurrent list in the federal system, where the central state and the regional states both have legislative powers, and the regional state governments can amend the central laws. Amendments to existing labour laws first appeared in the BJP-led state of Rajasthan in 2014, when the Industrial Disputes Act was amended to allow

\footnotetext{
${ }^{11}$ The union succeeded in settling a large wage rise of 10000 rupees for the permanent workers in 2014 (Nowak, 2019).

12 The different unions now have a formal body, Maruti Suzuki Workers' Union, to co-ordinate their actions (Nowak, 2019).
} 
employers not to seek permission from the state government before closing down units with fewer than 300 workers. The Contract Labour Act, which regulates irregular work, was amended to cover only companies that employed more than fifty workers, up from twenty workers. The Haryana state legislature passed the Industrial Disputes Amendment Act in 2016 to allow enterprises with up to 300 employees to lay off workers without the government's permission. It also copied the Contract Labour Amendment Bill of Rajasthan and amended the Factories Act of 1948 to exclude most of the lower tiers of the automobile supply chain from the purview of state regulation. Maharashtra, Tamil Nadu and Madhya Pradesh have implemented similar measures to exempt firms employing contract workers from the definition of factories. Through the central government scheme of the National Employability Enhancement Mission (NEEM) auto plants in Tamil Nadu have recruited temporary workers through the back door as apprentices. Workers allege that their unions are complicit in this new scheme that would reduce the bargaining power of permanent workers (Thozhilalar Koodam, 2018). The Modi state has proposed amending the Trade Union Act of 1926, the Industrial Disputes Act of 1947 and the Industrial Employment Act of 1946, with the objective of reducing and codifying the number of labour laws to ease implementation (Gopalan, 2016). Indian trade unions, including the BJP-affiliated Bhartiya Mazdoor Sangh, have taken stands against these labour reforms. They held a national convention on 26 May 2015 and conducted a national strike on 2 September 2015 against the central government reforms but have not been successful in derailing them. Meanwhile, MSIL continues to dominate the Indian automobile sector with a 53 per cent market share in passenger cars in 2016, and is recovering from a loss due to a global market crash in 2019 (Shyam and Thakkar, 2016; Indian Express, 2020). It has already started a new manufacturing plant and plans to start a second plant in Gujarat to make use of a more business-friendly industrial climate in Modi's home state. MSIL has also added around 5000 robots in its Gurgaon and Manesar plants, one way of replacing an unruly, demanding workforce.

\section{Fractured Militancy in China and India}

Autoworkers in China and India have faced a repressive production regime based on lean production and dual market strategies since a global uptick in production in 2010. It has been workers in the supplier plants in China who have carried the brunt of the dual market strategy that suppressed their wages in comparison to the core labour force of assembly plants that mobilised. In India, the mobilisation began in assembly plants, where the core labour force was not secure as in China and then spread to the supplier firms. The rising unrest was a concern of the Chinese provincial state, which initiated concessions such as wage hikes to remedy the grievances. This must be understood in the context of the long history of managing such grievances to maintain peace and stability in China (Hung, 2013). While there was a history of some concessions in India, the Suzuki strike led to massive suppression. While a few labour reforms were introduced by the Chinese state (followed by an era of repression with Xi Jinping's uncompromising approach), the anti-labour reforms introduced by the Indian state showed the country's prominent pro-business tilt.

The divergences are many: In India, there appears to be an even greater unity between state and capital than in China, where political concerns have far more significance for stability. Indeed, because the developing Indian automobile industry is far more reliant on global consumer markets, the unity of capital and the state tended to create a more rapacious response, including government support for strikebreaking, arrest of protesters, and incapacity or unwillingness to overturn the firing of all part-time informal workers. Nevertheless, there was 
more freedom of mobilisation and organisation in India, and the workers garnered the support of many trade unions and could seek alliances across the political space. In India, communitybound, local, regional and even international solidarity moves organically emerged under the anticipation of a potential working-class movement against global capitalism.

Though a comprehensive comparative analysis of state capacity and response is beyond the scope of this article, we would like to suggest that the Chinese and Indian states' differential responses emerge from their unique historical trajectories, particularly as relates to marketisation and legal development. Until the mid-1990s, China had no legal framework for regulating labour relations - "wage labour" was seen as a capitalist practice and was therefore wholly unacknowledged in the law. But the past twenty years have witnessed the construction of various institutions for regulating capitalist labour markets and employment relations. Despite a lack of formal democratic processes, the Chinese state has proven relatively responsive to growing labour unrest. India, on the other hand has maintained a protective set of labour laws since independence, though these never constituted a class compromise as in the North. Though provision of social citizenship was only for a small fraction of the workforce in the formal labour market, the state has consistently attempted to regulate the informal labour market through a series of protective legislations. Investors have long clamoured for a relaxation of labour protections, a position that has been enthusiastically embraced by the current right-wing government. Thus, given very different starting points on the eve of marketisation, China and India have been on opposing trajectories with respect to labour legislation, with the former moving towards greater regulation while the latter is embracing deregulation.

Relatedly, we found that the Indian state is more repressive towards striking workers. In both places, growth-obsessed local officials tend to side with employers in the resolution of labour conflict. The difference in India is that though it is extremely difficult to carry out a legal strike within the labour relations framework, workers have frequently dissented and justified their strikes based on democratic rights and freedoms (Nair, 2016). The somewhat counterintuitive consequence of this, however, is that the state is emboldened to crack down on workers who are engaged in "illegal" tactics such as wildcat strikes. In China, strikes are extra-legal - the law simply makes no mention of them one way or the other, with the exception of the previously mentioned instance in Guangdong. Always fearful that social conflicts could spin out control, the Chinese state has been rather circumspect in repressing striking workers. This is not to say that the police and courts never play a role in squashing dissent, and indeed recent evidence suggests stepped-up repression in Guangdong. But the regular police violence and mass criminalisation of dissent that we see in India has not appeared in China. This should serve as a reminder that fractured militancy may be a generalisable trend in the South, but that local historical conditions will continue to have a profound impact on the development of labour politics.

But the convergences are striking, too. Although the two countries followed very different economic and political trajectories since the 1950s, liberalisation and increased capital mobility have ushered in an incredibly hostile political terrain for labour over the past generation. A significant force in this regard has been economic decentralisation and the role of subnational states in encouraging and competing for attracting capital and promoting growth (Brenner, 1999). The provinces in China and the regional states in India assume a "catalytic role" in the expansion of multinational corporations (Weiss, 1998), leading to closer and often clandestine associations between state and capital, although the specific forms vary from province to province and region to region (Oi, 1992, 1995; Pieke, 1995; Jenkins, 2004; Sinha, 2005a, 2005b). Haryana and Guangdong are representative of this trend, with both places establishing specialised economic zones and pursuing employer-friendly policies over the past generation (Kennedy, 2014). As in 
many other places in the world, state-capital collusion is ascendent, marking a dramatic departure from socialist and nationalist legacies. While state hostility to labour is by no means a twenty-first century invention, the asymmetry in spatial mobility between capital and labour has widened, much to the advantage of the former. In our cases, this reality limits states' willingness to make significant pro-labour reforms. Foreign investors have been a powerful political force in both places, obstructing or watering down labour protections in China while consistently pushing for labour market liberalisation in India.

Yet another departure from twentieth-century labour politics in the automobile industry is the specific impact of Japanese-innovated employment segmentation introduced in the 1990s. Lean production demands intense production flow that elicits quick responses from labour and hence is predicated on full compliance by workers (Womack, Jones and Roos, 1990; Rinehart, Huxley and Robertson, 1997). This compliance is ensured to a certain extent by segmentation in the labour market, comprised of vertical segmentation within the firms, and horizontal segregation across the supplier firms. This has resulted in a core labour force rewarded with skills development, job security and wage rises. But this core coexists with a peripheral labour force without job security, skills development, high wages or substantial benefits. In China and India, the emergence of segmentation in the automobile sector has been well-documented and has had a profound impact on the nature of labour unrest (Gopalan, 2010; Zhang, 2011; Barnes, Das and Pratap, 2015). While segmentation has certainly not prevented worker protest altogether (Zhang, 2015), it has played a significant role in undermining intra- and inter-firm solidarity. In India, along with labour dualism, the shrinking permanent labour force and increasing mobility of capital within units, and the reserve army of labour created by the agrarian crisis in the economy have had a strong impact on the ability of workers to organise successfully after 2015 (Chakraborty and Jyoti, 2018). This segmentation of the workforce was not a feature of employment relations in the paradigmatic twentieth-century cases and presents workers with new challenges in organising politically.

Although the specifics are quite different, in both places twentieth-century unions have become tied to political parties, which greatly limits possibilities for reframing worker experience. The convention of having central trade unions affiliated to political parties created workers' movements that were split across party lines in India. In such an ideological and political context, it is not surprising that workers' resistance has been limited to workplace issues. Although worker resistance clearly lives on, there is no meta-narrative at hand to link seemingly particular struggles to broader movements for emancipation. While we do not suggest that this means contemporary worker struggles are apolitical - even demanding better representation on the shopfloor is a form of politics - it does suggest that political action faces immense difficulty in scaling up.

There is mounting evidence that trade unions no longer are the repository of society's interests and are less so the counterforces to neo-liberal globalisation. The weakening of their bargaining position vis-à-vis capital, lack of a durable political ideology, or even a fleeting class rhetoric to hold the workers together and engage them in collective action with long-term goals, have weakened them as mobilisational alternatives. The inability of the central unions to provide a unified platform for protesting workers was obvious in Gurgaon. Their inability to formulate strategies to counter the unapologetically pro-business National Democratic Alliance and to mobilise opposition effectively against the labour law reforms indicate that the heyday of unions formed in the twentieth century is probably over. The capacity of labour movements to organise, have sustained struggles and be successful has come to depend on their ability and willingness to form coalitions with transnational movements and NGOs and to align with broader concerns around environmental destruction and land dispossession. In China, the All-China Federation of 
Trade Unions certainly provides centralisation. But as is well-known, the ACFTU is subject to intensive control by the Communist Party and is generally subordinate to management at the firm level. Unions in China have no capacity to effectively articulate and advance the aspirations of a new working class. Social movements such as the Occupy movements, civil society and NGOs have become increasingly prominent, and unions have attempted to make coalitions with these movements to stay relevant. It is not surprising then that trade unions in the automobile sector, which have historically been the vanguards of organised unionism globally, epitomise this weakening of unions.

\section{Conclusion}

In this article, we examined labour unrest in the automobile industry in China and India against the backdrop of twentieth-century labour movements. Labour movements in the automobile industry in north-western Europe in the early- to mid-twentieth century pressured states to introduce reforms and extend social citizenship to the workforce. The late twentieth-century autoworkers' movements in Brazil, South Africa and South Korea contributed to regime change and democratisation. We have argued that China and India have, just as we might expect based on historical precedent, seen widespread militant resistance among auto workers. Nonetheless, this unrest has not elicited class-compromise-style reforms from the state, nor has it coalesced into a political force capable of bringing about broader political transformation. We have characterised this labour unrest as fractured militancy, by which we mean widespread contestation that cannot scale up from firm-based politics to an industry-wide or national movement.

Perhaps our conclusions are pre-emptive, given that the unrest is relatively recent, and it is premature to make a long-term prediction. We nevertheless contend that the micro foundations for a collective movement against global capitalism are not present in these protests. With several years of hindsight, it is apparent that these waves of unrest did not help to cohere the power of worker organisation, either in the factory or at the industrial level. Informalisation and segmentation of the workforce continues to be an obstacle to developing internal cohesion. And we have not witnessed the consolidation of a collective identity among the working class in China or India. In the absence of these conditions that played a role in twentieth-century labour movements, an intensifying ethno-nationalism - one that remains hostile to the interests of workers - seems to be filling the void in both places.

\section{References}

21 Shiiji Jingii Baodao (2010) Guangdong qiye minzhu guanli tiaoli re zhengyi, jiti xieshang cheng jiaodian. 21 Shiji Jingïi Baodo, 28 July 2010.

All China Data Center (2015) China Statistical Datasheet. https://www.china-data-online.com (accessed 21 January 2021).

Annavajhula, J.C.B. and S. Pratap (2012) Worker Voices in an Auto Production Chain: Notes from the Pits of a Low Road I. Economic and Political Weekly, 47(33): 45-59.

Barnes, T., K.S.L. Das and S. Pratap (2015) Labour Contractors and Global Production Networks: The Case of India's Auto Supply Chain. Journal of Development Studies, 51(4): 355-369.

Brenner, N. (1999) Globalisation as Reterritorialization: The Re-scaling of Urban Governance in the European Union. Urban Studies, 36(3): 431-451. 
Burawoy, M. (2008) The Public Turn: From Labour Process to Labour Movement. Work and Occupations, 35(4): 371-387.

Butollo, F. and T.T. Brink (2012) Challenging the Atomization of Discontent. Critical Asian Studies, 44(3): 419-440.

Chakraborty, A. and N. Jyoti. (2018) Changes in Production and Labour Regimes and Challenges before Collective Bargaining: A Study Focusing on the Gurgaon-Neemrana Industrial Belt in the DMIC. State of Working India, Background Paper 18, Azim Premji University.

Chan, C.K. and E.S. Hui (2014) The Development of Collective Bargaining in China: From "Collective Bargaining by Riot" to "Party State-Led Wage Bargaining". The China Quarterly, 217: 221-242.

Chen, F. (2003) Industrial Restructuring and Workers' Resistance in China. Modern Cbina, 29(2): 237-262.

Chen, Y.P. and A. Chan (2018) Regular and Agency Workers: Attitudes and Resistance in Chinese Auto Joint Ventures. The China Quarterly, 233: 85-110.

Chen, P. and M. Gallagher (2018) Mobilization without Movement: How the Chinese State "Fixed" Labour Insurgency. ILR Review, 71(5): 1029-1052.

D'Costa, A.P. (1995) The Restructuring of the Indian Automobile Industry: Indian State and Japanese Capital. World Development, 23(3): 485-502.

D'Costa, A.P. (2007) Economic Nationalism in Motion: Steel, Auto, and Software Industries in India. Review of International Political Economy, 16(4): 620-648.

Diamond, L.J. (1996) Is the Third Wave Over? Journal of Democracy, 7(3): 20-37.

Duara, P., and E.J. Perry (eds.) (2018) Beyond Regimes: China and India Compared. Cambridge: Harvard University Press.

Duvisac, S. (2019) Reconstituting the Industrial Worker: Precarity in the Indian Auto Sector. Critical Sociology, 45(4-5): 533-548.

Elfstrom, M. and S. Kuruvilla (2014) The Changing Nature of Labour Unrest in China. ILR Review, 67(2): 453-480.

Franceschini, I. and E. Nesossi (2018) State Repression of Chinese Labor NGOs: A Chilling Effect? The Cbina Journal, 80(1): 111-129.

Friedman, E. (2014) Insurgency Trap: Labour Politics in Postsocialist China. Ithaca, NY: Cornell University Press.

Friedman, E. and S. Kuruvilla (2015) Experimentation and Decentralization in China's Labour Relations. Human Relations, 68(2): 181-195.

Gallagher, M.E. (2017) Authoritarian Legality in China: Law, Workers, and the State. Cambridge, UK: Cambridge University Press.

Gereffi, G., J. Humphrey and T. Sturgeon (2005) The Governance of Global Value Chains. Review of International Political Economy, 12(1): 78-104.

Gongren Ribao (2016) Meiti xi lanyong laowu paiqian nan genzhi: you danwei jie ci taobi falü zeren. Gongren Ribao, 5 January 2016.

Gopalan, S.T. (2010) Cost Cutting Pressures and Labour Relations in Tamil Nadu's Automobile Components Supply Chain. In Labour in Global Production Networks in India, edited by A. Posthuma and D. Nathan. Delhi: Oxford University Press.

Gopalan, S.T. (2016) Withering Regulation? An Interim Review of Modi Government's Labour Reforms. Journal of Asian Public Policy, 9(2): 170-184.

Howell, J. and T. Pringle (2019) Shades of Authoritarianism and State-labour Relations in China. British Journal of Industrial Relations, 57: 223-246.

Huntington, S.P. (1991) The Third Wave: Democratization in the Late Twentieth Century. Norman, OK: University of Oklahoma Press. 
Hung, H.F. (2013) Protest with Chinese Characteristics: Demonstrations, Riots, and Petitions in the MidQing Dynasty. New York: Columbia University Press.

Indian Express (2020) Maruti Suzuki Reports 2 per cent Rise in Q2 Net Profit at Rs 1419 Crore. The Indian Express, 29 October 2020.

Jenkins, R. (ed.) (2004) Regional Reflections: Comparing Politics across India's States. Delhi: Oxford University Press.

Jha, P. and A. Chakraborty (2014) Post-Fordism, Global Production Networks and Implications for Labour: Some Case Studies from National Capital Region, India. Working paper 172. New Delhi: Institutions for Studies in Industrial Development.

Kennedy, L. (2014) Haryana: Beyond the Rural-Urban Divide. In Power, Policy, and Protest: The Politics of India's Special Economic Zones, edited by R. Jenkins, L. Kennedy, and P. Mukhopadhyay. New Delhi: Oxford University Press.

Koo, H. (2001) Korean Workers: The Culture and Politics of Class Formation. New York: Cornell University Press.

Kuruvilla, S. (2018) Editorial Essay - From Cautious Optimism to Renewed Pessimism: Labour Voice and Labour Scholarship in China. Industrual and Labour Relations Review, 71(5): 1013-1028.

Lau, R. (2012) Restructuring of the Honda Auto Parts Union in Guangdong, China: A 2-Year Assessment of the 2010 Strike. Working US A, 15: 497-515.

Lee, C.K. (2016) Precarization or Empowerment? Reflections on Recent Labour Unrest in China. The Journal of Asian Studies, 75(2): 317-333.

Lüthje, B. (2014) Labour Relations, Production Regimes and Labour Conflicts in the Chinese Automotive Industry. International Labour Review, 153: 535-560.

Make in India (2021) Automotive Mission Plan 2016-26. https://www.makeinindia.com/sector/automobiles (accessed 11 January 2021).

Nair, M. (2016). Undervalued Dissent: Informal Workers' Politics in India. Albany, NY: State University of New York Press.

Ness, I. (2016) Southern Insurgency: The Coming of the Global Working Class. London: Pluto Press.

Nowak, J. (2016) Strikes and Labour Unrest in the Automobile Industry in India: The Case of Maruti Suzuki India Limited. Working USA, 19: 419-436.

Nowak, J. (2017) Mass Strikes in India and Brazil as the Terrain for a New Social Movement Unionism. Development and Change, 48(5): 965-986.

Nowak, J. (2019) Mass Strikes and Social Movements in Brazil and India: Popular Mobilisation in the Long Depression. Germany: Springer International Publishing.

Oi, J.C. (1992) Fiscal Reform and the Economic Foundations of Local State Corporatism in China. World Politics, 45(1): 99-126.

Oi, J.C. (1995) The Role of the Local State in China's Transitional Economy. The China Quarterly, 144: 1132-1149.

Paret, M. (2018) From Passive Revolution to Fractured Militancy in South Africa. Paper presented at the International Sociological Association World Congress of Sociology, Toronto, Canada, 17 July 2018.

Pieke, F.N. (1995) Bureaucracy, Friends, and Money: The Growth of Capital Socialism in China. Comparative Studies in Society and History, 37(3): 494-518.

Posthuma, A. and D. Nathan (2010) Labour in Global Production Networks. Oxford: Oxford University Press.

Przeworski, A. (1986) Capitalism and Social Democracy. Cambridge, UK: Cambridge University Press.

Rinehart, J.W., C. Huxley and D. Robertson (1997) Just Another Car Factory? Lean Production and its Discontents. Ithaca, NY: Cornell University Press. 
Rodriguez, R.M. (2010) Migrants for Export: How the Pbilippine State Brokers Labour to the World. Minneapolis and London: University of Minnesota Press.

Sarkar, S. (2015) Murderous Violence at Work: Conflict and Aggression in Indian Auto Factories. Work Organisation, Labour \& Globalisation, 9(1): 38-62.

Seidman, G.W. (1994) Manufacturing Militance: Workers' Movements in Brazil and South Africa, 1970-1985. Berkeley, CA: University of California Press.

Seidman, G.W. (2007) Beyond the Boycott: Labour Rights, Human Rights and Transnational Activism. New York: Russel Sage Foundation.

Sethi, A. (2016) Violence at Maruti Symptomatic of Simmering Worker Discontent. The Hindu, 21 July 2016. https://www.thehindu.com/news/national/violence-at-maruti-symptomatic-of-simmeringworker-discontent/article3663050.ece (accessed 29 October 2019).

Shin, E. (2014) Unions and the Adoption of High-performance Work Systems in Korea: Moderating Roles of Firms' Competitive Strategies. The International Journal of Human Resource Management, 25(13): 1858-1880.

Shyam, A. and K. Thakkar (2016) Maruti Shares Touch All-time High. Economic Times Bureau, 3 August 2016.

Silver, B.J. (2003) Forces of Labour: Workers' Movements and Globalization since 1870. Cambridge, UK: Cambridge University Press.

Sinha, A. (2005a) Political Foundations of Market-enhancing Federalism: Theoretical Lessons from India and China. Comparative Politics, 37(3): 337-356.

Sinha, A. (2005b) The Regional Roots of Developmental Politics in India: A Divided Leviathan. Bloomington, IN: Indiana University Press.

Solinger, D.J. (2007) Labour Discontent in China in Comparative Perspective. Eurasian Geography and Economics, 48(4): 413-438.

Tozhilalar Koodam (Working Class Media) (2018) NEEM: A Mission to Deny Labour Rights - Ashok Leyland Workers Protest, January 17. https://tnlabour.in/automobile-industry/6335 (accessed 29 October 2020).

Wang, Y. and C. Minzner (2015) The Rise of the Chinese Security State. The China Quarterly, 222: 339-359.

Weiguang, Chen (interviewed by B. Lüthje) (2011) Trade Unions and Worker Struggles in Guangdong. Global Labour Column, Number 55, April 2011. http://column.global-labouruniversity.org/2011/01/trade-unions-and-worker-struggles-in.html (accessed 21 January 2021).

Weiss, L. (1998) The Myth of the Powerless State. Ithaca, NY: Cornell University Press.

Womack, J., D.T. Jones and D. Roos (1990) The Machine that Changed the World: The Story of Lean ProductionToyota's Secret Weapon in the Global Car Wars that is now Revolutionizing World Industry. United States: Free Press.

Xinhua Wang (2017) 31 shengfen zuidi gongzi paiming: shanghai 2300-yuan ju shou, xizang, guangxi, diandi. Xinhua Wang, 17 July 2017.

Zhang, L. (2011) The Paradox of Labour Force Dualism and State-Labour-Capital Relations in the Chinese Auto Industry. In From Iron Rice Bowl to Informalization: Markets, Workers and the State in a Changing China, edited by S. Kuruvilla, C.K Lee and M.E. Gallagher. Ithaca, NY: Cornell University Press.

Zhang, L. (2014) Whose Hard Times? Explaining Autoworkers Strike Waves in Recent-day China. In Workers in Hard Times: A Long View of Economic Crises, edited by L.F. Joseph, A. McCartin and J. Sangster. Champaign, IL: University of Illinois Press.

Zhang, L. (2015) Inside China's Automobile Factories: The Politics of Labour and Worker Resistance. Cambridge, UK: Cambridge University Press. 


\section{ACKNOWLEDGEMENTS}

Hao Zhang contributed invaluable research assistance. We thank two anonymous reviewers of the Global Labour Journal for their valuable suggestions. Mathew Abraham, Ellen David Friedman, Suresh T. Gopalan, Sarosh Kuruvilla, Gautam Mody, Partha Nath Mukherji, Surendra Pratap, Qian Qin and Yang Tao provided immensely helpful insights and sources of information. Earlier versions of this paper were presented at the American Sociological Association Annual Meeting, Brown University's conference "Transformative Possibilities in the Global South", as well as Cornell University's ILR School Seminar Series.

\section{BIOGRAPHICAL NOTES}

MAnjusha NAIR is Associate Professor of Sociology at George Mason University. Her research has been on the possibilities and limitations of the counter-hegemonic processes that challenge neo-liberal globalisation in the Global South. Her award-winning book, Undervalued Dissent: Informal Workers' Politics in India (SUNY Press, 2016), showed, systematically, how neo-liberal globalisation, mediated as market fundamentalism and right-wing politics in India, has weakened the ability of rural migrant workers to use democratic forms of contention, ranging from negotiations to strikes and social movements.

[Email: mnair4@gmu.edu]

ELI FRIEDMAN is Associate Professor in the ILR School's Department of International and Comparative Labor at Cornell University. His work focuses on migrant labour and urbanisation in China. He is the author of Insurgency Trap: Labor Politics in Postsocialist China (Cornell, 2014).

[Email: edf48@,cornell.edu] 